\title{
EFFECT OF SOAKING SEEDS IN, A MIXTURE OF CHELATED FE, MN AND ZN SOLUTION WITH AGAR AS A CARRIER, ON THE YIELD AND YIELD COMPONENT OF RICE (Oryza sativa L.) \\ Attia, Manal A.; H. G. Abou EL-Fotoh; S. M. M. Allam and Eglal E. M. EL-Aggory \\ Plant Nutrition Res.Sec., Soils, Water and Environment Res.Inst. Agricultural Res.Center (ARC), Giza - Egypt
}

\begin{abstract}
Rice is one of the major food and economic crop in Egypt. In a trial to improve grain yield ,two field experiments were carried out on clayey soil during two successive summer seasons(2004 and 2005)at Sakha Experimental Research Station $(A R C)$, to study the effect of soaking rice seeds for 48 hours before sowing in a nutrient solution containing a mixture of chelated $\mathrm{Fe}, \mathrm{Mn}$ and $\mathrm{Zn}$ at $0.2 \%$ each , with or without the biopolymer agar at $0.2 \%$ as a carrier, on the yield, yield components and chemical composition of rice grain variety Sakha 104.

The obtained results revealed that applying micronutrients by seed soaking method was very effective in improving grain and straw yields, with highly significant increase of $14.5 \%$ over control as an average of the two seasons. Also, it improved the intake of macro and micronutrients in grain yield /feddan. On the other hand, using agar at $0.2 \%$ with or without micronutrients in soaking solution had no effect on yield of grain ,straw yield and chemical composition of grains.
\end{abstract}

\section{INTRODUCTION}

Fertilizer use should be balanced and optimized to obtain the highest possible efficiency with less environmental pollution .The micronutrients should become an integral part of balanced fertilization program .Symptoms of $\mathrm{Fe}, \mathrm{Mn}$ and $\mathrm{Zn}$ deficiencies are widespread in Egypt, and treating crops with micronutrients led to increase in yield with high net return(El-fouly and Fawzi 1996 and Monged et al., 2003) .Seed treatment with micronutrients by coating or soaking before sowing are valuable although they were less effective than foliar application (Ghaly et al.,1992,Amin et al.,1998 and Badr et al.,1998). Moreover, it is advantageous in terms of scale up, cost and ease in operation.

Soaking method appeared to be suitable for rice, as seeds as usually soaked in water for 48 hours before sowing. Monged and Mawardi (1978) and Korayem (1993) noted that soaking rice seeds in zinc sulphate solution increased yield of grains, as it increased germination, Wang and Song (2005),improved seedling vigour and plant growth (Jeybal and Kuppuswamy, 1998).

In a trial for increasing the efficiency of coating method,Zhang and Mao (1992) found that mixing zinc sulphate with a coagulant colloid in seed treatment led to the highest increase in yield .

In this respect, EL- Aggory et al.(2002, a\&b) noted that mixing the biopolymer agar at $0.1 \%$ with the nutrient solution used for soaking seeds increased seedling growth of wheat and yield of peanut grown on sandy and calcareous soils . 
Attia, Manal A. et al.

The present investigation was carried out to study the effect of soaking rice seeds in a solution containing a mixture of chelating $\mathrm{Fe}, \mathrm{Mn}$ and $\mathrm{Zn}$ with agar as a carrier, on yield components and chemical composition of grains.

\section{MATERIALS AND METHODS}

To realize the effect of agar on the response of rice plant to micronutrients ,two field experiments were conducted in two successive seasons (2004 and 2005) at Sakha Experimental Station, Kafr -El-Sheikh Governorate, which is considered one of the important localities for rice production in Egypt.

Surface soil samples $(0-30 \mathrm{~cm})$ from the experimental field, were analyzed as shown in Table (1). Seeds of rice were soaked for 48 hours in the following different solutions :

(1) Control (In water ).

(2) Agar solution of $0.2 \%$.

(3) Nutrient solution containing the three chelating micronutrients $\mathrm{Fe}, \mathrm{Mn}$ and $\mathrm{Zn}$ at the concentration of $0.2 \%$ for each.

(4) Agar solution of $0.2 \%$ containing the above three micronutrients. Such technique was similar to that developed by EL- Aggory et al. (2002 b).

Experimental fields of both seasons were prepared and divided to plots $\left(10 \mathrm{~m}^{2}\right)$ and the treated seeds were sown in rows $20 \mathrm{~cm}$ apart.

All plots received superphosphate and potassium sulphate at the rate of $15 \mathrm{~kg} \mathrm{P} \mathrm{O}_{5}$ and $24 \mathrm{~kg} \mathrm{~K} \mathrm{~K}_{2} \mathrm{O} /$ feddan, respectively, before sowing ,while urea was applied in two equal split doses ,30 days after sowing and 15 days later at the rate of $60 \mathrm{~kg} \mathrm{~N} / \mathrm{feddan}$. Thus, four treatments were designed in a complete randomized block with four replicates.

At harvest, grain and straw yields were recorded as ton /feddan. Grain samples from each treatment were taken for chemical analysis and wet digested using $\mathrm{H}_{2} \mathrm{SO}_{4}$ and $\mathrm{HCLO}_{4}$ acids mixture. N,P, and $\mathrm{K}$ were determined according to Chapman and Pratt (1961), while Fe, Mn and $\mathrm{Zn}$ were determined using Atomic Absorption Spectrophotometer apparatus (GBC 933).

Yield data were statistically analyzed for each experiment and combined analysis was determined according to Snedecor and Cochran (1972).

\section{RESULTS AND DISCUSSION}

Soil analyses data recorded in Table (1) reflect the characteristics of clayey soils in Sakha.

Being they were fairly high in $\mathrm{PH}$ with moderate salinity. Available nutrient concentrations show low content in total soluble nitrogen fairly adequate content of available phosphorus and satisfactory content of potassium. These analyses were carried out as described by Jackson (1973). As for micronutrients contents in DTPA extract, $\mathrm{Fe}$ and $\mathrm{Mn}$ were adequate, while Zn was low according to Lindsay and Norvell (1978). 
J. Agric. Sci. Mansoura Univ., 32 (8), august, 2007

Table(1):Some physical and chemical properties of the experimental soils

\begin{tabular}{|c|c|c|c|c|c|}
\hline \multicolumn{3}{|c|}{ Physico-chemical properties } & \multicolumn{3}{c|}{ Available nutrients (mg/kg $\mathbf{~}^{\mathbf{1}}$ ) } \\
\hline & $\mathbf{2 0 0 4}$ & $\mathbf{2 0 0 5}$ & & $\mathbf{2 0 0 4}$ & $\mathbf{2 0 0 5}$ \\
\hline Clay \% & 56.70 & 55.00 & $\mathrm{~N}\left(2 \% \mathrm{~K}_{2} \mathrm{SO}_{4}\right)$ ext. & 38.00 & 40.00 \\
Silt \% & 23.80 & 24.40 & $\mathrm{P}\left(\mathrm{NaHCO}_{3}\right)$ ext. & 10.00 & 8.70 \\
Sand \% & 19.50 & 20.60 & K(NH4OAC)ext. & 378.0 & 269.0 \\
Texture class & clayey & clayey & Zn (DTPA).ext. & 0.48 & 0.61 \\
EC mmohs/cm & 1.50 & 1.30 & Fe (DTPA).ext. & 8.30 & 7.90 \\
PH & 8.20 & 8.30 & Mn (DTPA).ext & 11.8 & 12.60 \\
\hline
\end{tabular}

*pH:in(1:2.5)soil water suspention.

${ }^{*} \operatorname{Ec}:$ in(1:5)water extract.

Yield and yield components data presented in Table (2) show the effect of different treatments on grain and straw yields, grain /straw ratio and the weight of 1000 grain.

Table(2):The effect of different soaking treatments on rice yield and yield components

\begin{tabular}{|c|c|c|c|c|c|c|c|c|c|c|}
\hline Sea & 20 & 04 & 20 & 05 & Mea & an of the $t$ & two sea & asons & & \\
\hline 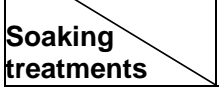 & $\begin{array}{l}\text { Grain } \\
\text { yield }\end{array}$ & $\begin{array}{l}\text { Straw } \\
\text { yield }\end{array}$ & $\begin{array}{l}\text { Grain } \\
\text { yield }\end{array}$ & $\begin{array}{l}\text { Straw } \\
\text { yield }\end{array}$ & $\begin{array}{l}\text { Grain } \\
\text { yield }\end{array}$ & $\begin{array}{c}\% \\
\text { increase }\end{array}$ & $\begin{array}{l}\text { Straw } \\
\text { yield }\end{array}$ & $\begin{array}{c}\% \\
\text { increase }\end{array}$ & $\begin{array}{c}\text { /straw } \\
\text { ratio }\end{array}$ & $\begin{array}{c}\text { graln } \\
\text { weight } \\
\text { (9) }\end{array}$ \\
\hline Control(in water) & 2.228 & & 2.185 & 33 & 2.206 & 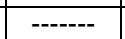 & 5.473 & ------- & $1: 2.48$ & 28.3 \\
\hline Agar $0.2 \%$. & 2.127 & 2 & 2.1 & 5.2 & & ------- & & ------- & $1: 2.422$ & 28.25 \\
\hline \begin{tabular}{|l|} 
Micronutrients \\
$0.2 \% .(F e+M n+Z n)$
\end{tabular} & $2.517^{\star \star}$ & $6.275^{\star \star}$ & $2.550^{\star \star}$ & $6.183^{\star \star}$ & $2.534^{\star \star}$ & 15 & $6.229^{* *}$ & 14 & $1: 2.458$ & 27.5 \\
\hline $\begin{array}{l}\text { Agar and } \\
\text { micronutrientes }\end{array}$ & & $6.335^{\star *}$ & $2 *$ & $6.228^{\star *}$ & $2.514^{\star *}$ & 14 & $6.281^{* *}$ & 15 & $1: 2.498$ & 27.3 \\
\hline L.S.D. 5 & \begin{tabular}{|l|}
0.145 \\
0.209 \\
\end{tabular} & $\begin{array}{l}0.376 \\
0.541 \\
\end{array}$ & $\begin{array}{l}0.162 \\
0.233 \\
\end{array}$ & $\begin{array}{l}0.376 \\
0.541 \\
\end{array}$ & $\begin{array}{l}0.117 \\
0.160 \\
\end{array}$ & & $\begin{array}{l}0.235 \\
0.320 \\
\end{array}$ & & & \\
\hline
\end{tabular}

\section{Grain yield}

Data reveal that agar had no effect on the different characters under study when used either alone or in combination with micronutrients. Such results were in agreement with that obtained by EL-Aggory et al. (2002 a\&b) with wheat grown in heavy clayey soil at Sakha. It seems that agar acts like clay colloids in retaining water and nutrients that alleviate agar effect, as agar was very effective in sandy and calcareous soils. However, Zhang and Mao (1992) obtained an increase in rice yield on mixing zinc sulphate with coagulant colloid in seed treatment.

Examining further such data it can be noted that the application of micronutrients with or without agar caused a high significant increase of about 15 and $14 \%$, respectively, for both seasons, while, the average of both seasons was $14.5 \%$. Thus, this increase can be attributed to micronutrients only. Also, such increase indicates the efficiency of applying micronutrients by seed soaking method in correcting micronutrients deficiency that improve nutrient balance, use of NPK fertilizers and yield in turn.

Furthermore, it indicates the deficiency of experimental soil in available micronutrients especially $\mathrm{Zn}$. High soil $\mathrm{pH}$ and high clay proportion in the soil could have probably lowered the availability of micronutrients to plants (Table 1). EL- Fouly and Fawzi (1996) and Monged et al. (2003) noted 
Attia, Manal A. et al.

that deficiency of micronutrients has become a limiting factor for yield production in many location in Egypt .Ghaly et al. (1992), Amin et al. (1998) and Badr et al. (1998) obtained significant yield increases on treating seeds with micronutrients and added that a mixture of them was more effective than using any of them individually. The increase in crop production resulted from micronutrients application can be ascribed to their multifunctional role in growth and metabolism of plant. Wang and Song (2005)noted that soaking rice seeds in $\mathrm{Zn}$ solution at a concentration of $0.3 \mathrm{mg} / \mathrm{L}$, led to increases in germination rate, seed activity and membrane penetration of seeds .In addition, Abou EL-fotoh et al. (2006) observed that crop yields of rice responded significantly to micronutrients spray and recorded an increase of $22 \%$ for rice grain yield .

Weight of 1000- grains:

the slight increase in 1000 grain weight in control and agar treatments than in micronutrients ones was a contrast to that obtained with grain yield (Table 2), may refer to more filling of grain .Also, it may explain that fertilizer use is still need to be optimized and balanced to achieve higher yield with better quality.

Straw yield:

Straw yield data presented in Table (2) reveal that the beneficial effect of applying micronutrients by soaking method on straw yield was as that observed with grain yield .A highly significant increase of $14.5 \%$ over control was the average obtained in both seasons. Using agar alone or in combination with micronutrients had no clear effect on straw yield.

Grain /straw ratio:

Calculating the ratio between grain and straw yield, Table (2) displays that there is no appreciable difference or trend among the different treatments . This may be due to the same average increase of $14.5 \%$ in grain and straw yields as a result of ionic balance caused by micronutrient application.

\section{Chemical composition:}

Examining further the analytical data of grain in Table (3), it can be noted that treatment of micronutrients alone exhibited the highest concentration and content of nutrients, while agar with micronutrients or agar alone showed less values. Such results may explain the effect of balance between macro and micronutrients in the first treatment, while, they show that agar may lead to fixation of nutrients like clay colloid as noted before by EL-Aggory et al. (2002,b).

Nutrient intake

Calculating total uptake of nutrients in grain yield /feddan in Table (4), it can be noted that micronutrient treatment caused the highest increase in macro and micronutrients. In this respect, EL- Fouly and Fawzi (1996) noted that micronutrients application led to increased root growth and thus higher uptake of N,P and $\mathrm{K}$ and yield in turn. 
Table (3): The mean nutrient concentrations in rice grains of both tested seasons as affected by different soaking treatment

\begin{tabular}{|l|c|c|c|c|c|c|c|}
\hline \multirow{2}{*}{ Treatments } & \multicolumn{3}{|c|}{ Macronut.conc. (\%) } & \multicolumn{5}{|c|}{ Micronut.Conc.ug/g } \\
\cline { 2 - 8 } & $\mathbf{N}$ & $\mathbf{P}$ & $\mathbf{K}$ & $\mathbf{F e}$ & $\mathbf{M n}$ & $\mathbf{Z n}$ & $\mathbf{C u}$ \\
\hline Control & 0.64 & 0.80 & 3.00 & 170 & 47.0 & 16.0 & 8.0 \\
\hline Agar & 0.46 & 0.60 & 2.00 & 126 & 33.0 & 19.0 & 7.0 \\
\hline Micronut. & 0.70 & 0.67 & 3.00 & 243 & 50.0 & 30.0 & 9.0 \\
\hline Agar+Micronut. & 0.58 & 0.87 & 3.00 & 182 & 41.0 & 25.0 & 6.0 \\
\hline
\end{tabular}

Table (4): The mean nutrient contents in rice grains of both tested seasons as affected by different soaking treatment

\begin{tabular}{|l|c|c|c|c|c|c|c|}
\hline \multirow{2}{*}{ Treatments } & \multicolumn{3}{|c|}{ Content (kg/feddan) } & \multicolumn{3}{|c|}{ Content (g/feddan) } \\
\cline { 2 - 8 } & $\mathbf{N}$ & $\mathbf{P}$ & $\mathbf{K}$ & $\mathbf{F e}$ & $\mathbf{M n}$ & $\mathbf{Z n}$ & $\mathbf{C u}$ \\
\hline Control & 14.11 & 17.65 & 66.18 & 375.0 & 103.68 & 35.29 & 17.7 \\
\hline Agar & 09.84 & 12.83 & 42.78 & 269.5 & 70.58 & 40.64 & 14.9 \\
\hline Micronut. & 17.73 & 16.98 & 76.02 & 615.8 & 126.70 & 76.02 & 22.8 \\
\hline Agar+Micronut. & 14.58 & 21.87 & 75.42 & 457.6 & 103.07 & 62.85 & 15.1 \\
\hline
\end{tabular}

\section{Conclusion:}

In the light of the obtained results, it can be concluded that application of micronutrients to rice by seed soaking method, proved to be effective in correcting deficiencies, economical and easy to adopt. Also, fertilizer use is still need to be balanced and optimized to achieve higher yield with better quality.

\section{REFERENCES}

Abou EL-Fotoh, H.G.; A. A. Abd EL-Magid, Manal, A. Attia; M. A. ELAkabawy and Nadia, O. Monged (2006). The effectiveness of putrescine and micronutrients treatments in improving the yield of wheat and rice crops under soil salinity conditions. Egypt. J. Appl. Sci., 21(A):321-328.

Amin,M.A.A.; M. M. Badr,T. A. Abou El-Defan and Nadia, O.Monged (1998). Application of $\mathrm{Fe}, \mathrm{Mn}$ and $\mathrm{Zn}$ by different methods and their effects on yield and mineral composition of maiz. J. Agric. Sci. Mansoura Univ.,23(7):3539-3547.

Badr, M.M.; S. A. Abd EL-Rehim, T. A. Abou EL- Defan and Nadia, O. Monged (1998). Effect of different methods of some micronutrients applications on yield, chemical content and some fiber properties of cotton Giza 77 C.V.Egypt.J. Appl. Sci., 13(7): 365-373.

Chapman, H. D. and F. P. Pratt (1961). " Soils, Plants and Methods of Water analysis". Univ. of Calif., USA. 197-200.

EL-Aggory, E. M. Eglal and Sh. M. Abd EL Rasoul EL-Aggory, E. M. Eglal and Sh. M. Abd -EL Rasoul.(2002 a).The biopolymer, Agar Agar, as soil conditioner : part I. Green house experiments: Egypt. J. Agric. Res.80(1):1-12.

EL-Aggory, E. M. Eglal and Sh. M. Abd EL Rasoul (2002 b).The biopolymer, Agar Agar, as soil conditioner: Part II. Field trials. Egypt J. Agric. Res.80(1)

EL-Fouly, M. and A. Fawzi, A. (1996).Fertilizer Use in the Near East Agriculture Over View. Regional Workshop on Fertilizer use for Sustainable Agriculture. Amman, Jorden 4-6. 
Ghaly, S.; A. O. Osman, and A. Abou-Bakr, (1992).The effect of applying micronutrient fertilizer by coating method on wheat. Fifth Botanical Conference, Sant Catherine, Sinai Egypt. April 28-30.

Jackson, M.L. (1973). Soil Chemical Analysis. Printice Hall. Inc. England Cliff. $\mathrm{N}$.

Jeyabal, A. and G. Kuppuswamy (1998).Effect of seed soaking on seedling vigour, growth and yield of rice. J. Agron. and Crop Sci., 180 (3):181190.

Korayem, A. M. (1993). Effect of zinc fertilization on rice plants and on the population of the rice-root nematoda Hirschmanniella oryzae. Aczeiger fur Schadlingsjunde, Pflonzenschutz, Umweltschutz. 66 (1): 18-21.

Lindsay ;W.L. and W. A. Norvell (1978). Development of a DTPA soil test for $\mathrm{Zn}, \mathrm{Mn}$., Fe. and Cu. Soil Soc. Amer.J., 42:421-427.

Monged, Nadia O. and A. Mawardi(1978). Effect of different levels of zinc on some rice varities. Agric. Res. Rev., Ministry of Agriculture, Cairo, 64.

Monged, Nadia O.; M. A. EL-Akabawy; Magda, A.Ewais and Amina, M.Abd EL-Latife (2003). A trial towards the integrated cotton plant nutrition for higher economic yield in some soils of Egypt. Egypt. J. Appl. Sci., 18(6):377-387.

Snedecor, G.U.; and W. G. Cochran, (1972)."Statistical Methods" $6^{\text {th }}$ ed. lowa State Univ., Press lowa. USA.

Wang, Xiaobo and Song, FengBin. (2005). A study on the effect of zinc on germination of rice. Journal of Jilin Agricultural university, 27 (2):119122.

Zhang, C.L. and D. Mao (1992). Effect of zinc application with seed coating formulation (Zn-SCF) as a carrier on the growth of rice and maize. International Symposium on the role of sulpher, magnesium and micronutrients in balanced plant nutrition. 257-261.

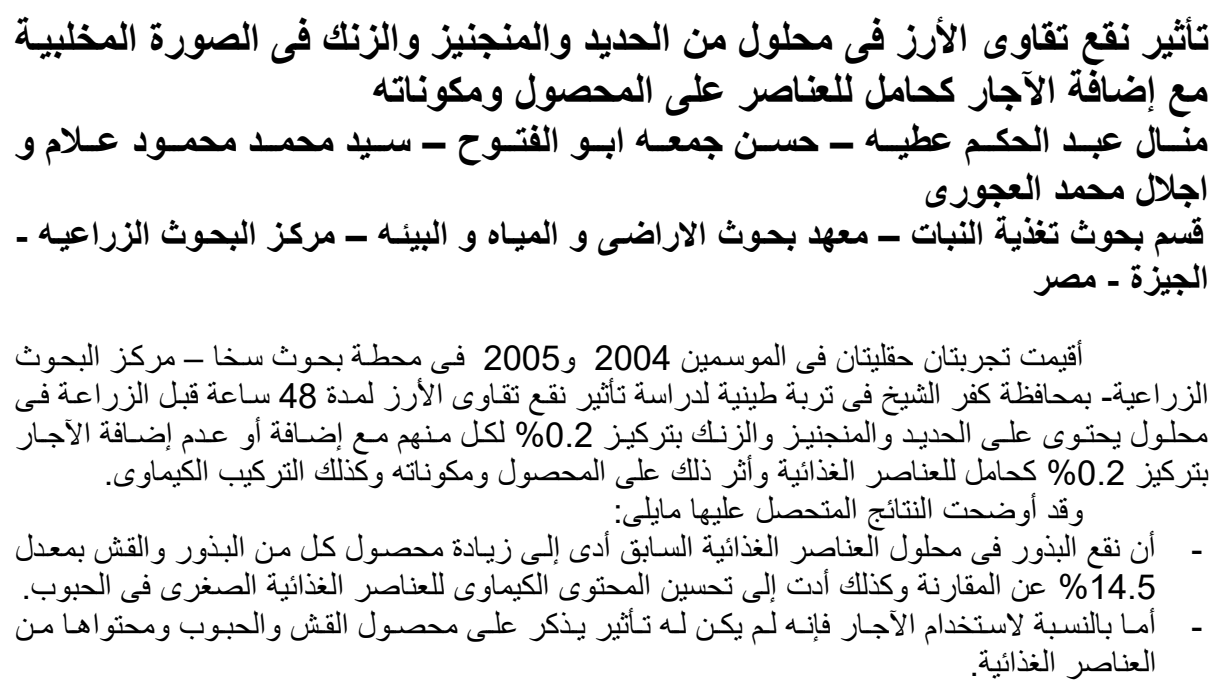

